\title{
THE POTENTIAL FOR INTER-INSTITUTIONAL COOPERATION FOR SHARIA ACTUARY NON-CERTIFICATION PROGRAMS FOR SHARIA INSURANCE IN INDONESIA
}

\author{
Alfiah Hasanah', Cupian², Eko Fajar Cahyono ${ }^{3}$, Lina Nugraha Rani ${ }^{4}$ \\ 1,2Department of Economics, Faculty of Economics and Business, Padjajaran \\ University, Bandung \\ 3.4Departmen of Islamic Economics, Faculty of Economics and Business, Airlangga \\ University, Surabaya \\ 'Email: alfiah@unpad.ac.id (Correspondence Author) \\ 2Email: cupian@fe.unpad.ac.id \\ 3Email: ekofajarc@feb.unair.ac.id \\ 4Email: linanugraha@feb.unair.ac.id
}

\begin{abstract}
This study aims to explore the potential model of collaboration among institutions such as the Financial Services Authority $(\mathrm{OJK})$ as regulators, higher education institutions, general higher education institutions and religious higher education, sharia insurance industry associations, actuary professional associations and sharia insurance companies to carry out non-sharia certification of the sharia actuary profession. This study uses descriptive qualitative approach and literature study method. The results of the study recommend that certification programs that span sharia actuaries require several institutional roles including Financial Services Authority (OJK), National Sharia Council (DSN), Indonesian Ulema Council (MUI), Indonesian Syariah Insurance Association (AASI) and Indonesian Actuary Association (PAI). Each agency has their respective duties and functions such as regulators, prospective actuary providers, distance education providers, certification providers, and material providers.
\end{abstract}

Keywords: Distance Certification, Sharia Actuary, Sharia Insurance 


\section{Introduction}

Financial Services Authority (OJK) has issued a 2015-2019 Sharia Non-Bank Financial Industry (Sharia IKNB) development plan which contains the vision, aspirations and target targets for the development of the Sharia Non-Bank Financial Industry (Sharia IKNB) in Indonesia. A critical point of concern is how to increase the quantity and quality of human resources in the Sharia Non-Bank Financial Industry (Sharia IKNB) in Indonesia. The quality and quality of human resources in Sharia NonBank Financial Industry (Sharia IKNB) is a very strategic and crucial issue. Along with the growth of Sharia Non-Bank Financial Industry (Sharia IKNB), the demand for qualified and qualified human resources is inevitable. According to Financial Services Authority (OJK), there is still a gap between the needs and availability of human resources in the Sharia Non-Bank Financial Industry (The Sharia Non-Bank Financial Industry Directorate-Financial Services Authority, 2015).

Today the actuary profession is an essential profession for the non-bank financial industry. The function of an actuary is as a person who assesses the risk of insurance policyholders, the risk of such dangers as the risk of death, the risk of serious illness, the risk of accidental fire risk and so on. The risk assessment will determine how much the insurance policyholder must pay the premium and how many claims must be paid by the insurance participant. In essence, an actress will estimate the probability or possibility of risk. The risk is very closely related to the insurance business because basically, the insurance business is how the company takes over the threat from the policyholder. Errors in determining the risk assessment will make the insurance company make a mistake in setting the premium cost and established the claim holder's fee; the insurance company will bear the loss. The role of the actuary also included as a person who calculates risks that will be faced by insurance companies that cover business risks and financial risks (Ali, 2009).

One of the most significant problems faced by Islamic insurance companies is the lack of actuary power. Actuary scarcity occurs in most countries and is no exception in Indonesia. Actuary scarcity does not only happen in Islamic insurance but also in conventional insurance. Actuary power demand is increasing from time to time due to the growth of the broader insurance industry and the need for professionalism. This high demand not balanced with adequate supplies. This imbalance reflected in the existing data that the number of actuaries in Indonesia is only 150 people and the need for actuaries in Indonesia reaches 1800 people. Likewise, the situation of other countries such as Malaysia, and Muslim countries such as Pakistan or Saudi Arabia, and the United Arab Emirates Unit (www.bisnis.tempo.co).

Another crucial issue other than actuary quantity is the issue of competence and qualifications for Islamic insurance actuaries. The expected sharia actuary competence is different from conventional actuaries. Sharia insurance actuaries become a business partner with the value of Islamic teachings so that sharia insurance in carrying out its business based on sharia principles. The principle of Islamic law in the context of financial institutions is the prohibition of 5 things, namely maysir (speculation, gambling), gharar (unclear/doubtful), riba (interest), tadlis (fraud), and dhalim. The implication of the application of these principles is that assessment and risk calculation is the basis for determining premiums, and the cost of risk claims between general insurance and traditional insurance is different (Kurnia, 2017).

The difference in operational principles between sharia insurance and current insurance results in different human resource competency needs between the two. Shariah actuary qualifications are more complex and more complicated than general actuary competencies. Islamic insurance actuaries are required to master hard skills, soft skills, and character skills. Hard power is the ability obtained from formal education benches such as school or university or certification institution. The skills that must be possessed by Islamic actuaries among others are mathematical abilities, statistics, and probability theory with which the actuary can predict, assess and measure risk. Hard skill competence which is a unique characteristic of sharia 
actuaries is the ability to understand Islamic teachings, Islamic law, fiah, muamalah figh, and figh proposals and ethics and can read Al-Quran because a sharia actuary is obliged to fulfill sharia compliance in carrying out his profession. Sharia compliance is a benchmark for the success of Islamic insurance and is the main differentiator of Islamic insurance with conventional insurance.

With sophisticated and complicated qualifications, searching for an actuary with the composition mentioned in the previous paragraph is not an easy matter. From the data compiled from various sources, that for conventional insurance in Indonesia also still lacks actuaries, it can also conclude that for sharia insurance that its market share compared to traditional coverage is relatively small, lack of actuary is too absolute.

Various factors are thought to be the cause of the shortage of actuary power in Indonesia. The first factor is the number of majors or study programs. The actuarial study program classified as a very new study program in Indonesia, until now there are only a few universities that open actuarial study programs such as the Bandung Institute of Technology (ITB) and the Ten November Institute of Technology (ITS) in Surabaya which began the study program this year (www.ristekdikti.go.id).

Actuarial science is not as developed as mathematics and statistics which has many study programs and is very long-lived. Unlike in Western countries such as England and America which have strong actuarial science developments, even one actuarial faculty at universities in the United Kingdom (UK) has turned 180 years old, while Indonesia actuarial science is considered a new science and is known as a combination of several sciences from mathematics, accounting, and economy. The second factor is the lack of public understanding of the actuary profession, this profession perceived as foreign and new, and not many know what an actuary is and what is the duty. Even though today, the job of an actuary is the most expensive salary profession in the world and in Indonesia.

The third factor is about the development of the financial industry, the development of the non-bank financial industry such as insurance and pension funds also influences the popularity of the actuary profession. Unlike leading bank institutions, the market penetration of the nonbank financial sector is still less, so that the reputation of the actuary profession is not yet fully known, the image in the public mind that being an employee in the insurance company is concerned with marketers promoting door-to-door insurance products and this assumption is not entirely correct (Djaelani, 2011).

The fourth factor is the socio-economic problem of the Indonesian people, a very high level of heterogeneity, such as different income levels and different levels of education. The majority of the Indonesian population cannot get a college education because of various economic abilities, from those who have tertiary education, if sorted out, there will be few people who choose to take the department or study program in mathematics or statistics (Dwiharjo, 2015)

The fifth factor that is suspected to be the lack of an actuary is the process of being a long and winding actuary, to become an actuary one has to go through a certification process which consists of receiving material and examinations that are not small other than that the costs incurred are not cheap.

Although many driving factors cause the least number of actuaries, there are also potential factors that can trigger the development of the actuary profession in Indonesia, such as the large population, because labor is the main driving factor in the company, even though the company has capital and physical capital. Adequate, without any personal money the company cannot do much. The large population is an excellent source of actuary energy.

The second potential factor is Indonesia's youth interest in employment, Indonesia is known as the country with the highest educated unemployment in the world. Educated youth still want jobs that are in line with their educational qualifications. At every fair job event, it will often found that participants will boom even queve up - queue as well as when the government opens civil service vacancies. So many people will flock to the selection process, the profession as a public servant of the State becomes excellent because considered honorable and 
has a clear career path and a clear pension fund (www.beritasatu.com).

According to some research, aspects of work are important aspects that determine the level of life satisfaction. Even many parents carry out bribery to find a job for their children. Indicators that have mentioned earlier show that Indonesians have a desire to work and if they know the benefits, salaries, and welfare of the actuary profession, their interest in the actuary profession will also be very high.

The third potential factor that needs to be noted is the inherent intelligence of Indonesian youth and children. From various news sources, there can be a lot of news that many Indonesian children have achieved brilliant achievements in mathematics, statistics, and other sciences. The result proves that the analytical and logical abilities of the Indonesian people are not inferior to other nations. Analytical and logical skills are essential capital for an actuary in carrying out his profession.

The fourth potential factor is the education system of universities in Indonesia which leads to student center learning. This system has the spirit to form student competencies clearly and accurately. In this latest curriculum, the output is in addition to diploma, a certificate of expertise that explains the competence and knowledge of students. This curriculum focuses on skills that must be mastered by students so that they can compete in the face of the world of work (Center of Educational Development-Gadjah Mada University, 2010).

In the era of digital information like today, a breakthrough arises how to make labor supply available more quickly. One of these breakthroughs is the existence of distance education or distance training. This method allows students not to meet face to face with teachers and lecturers directly but with online media. The distance education process becomes more flexible and saves costs and time. Some of these benefits can be an alternative solution to the problem of actuarial scarcity in Indonesia. Online education or certification is believed to have bright prospects in the future.

At present, technological sophistication has changed the dynamics of all aspects of human life, including education. Dozens or even tens of years ago, the public might never have thought about distance education without face to face, but thanks to technological sophistication now it was not an impossible thing to do. Now, distance education has realized the ideals of many people who are constrained by distance and time, to pursue higher education in various universities in the world. Distance education practices currently use internet technology as a supporting tool. The lecture system together with the lecturers is done through online video conferencing so that lectures that usually done in the classroom can now be done through video calls from their homes (Kuntarto, 2017).

Allen, Elaine, dan Seaman (2017) refers to the Distance Education Enrollment Report 2017, which notes that in the United States no less than 6 million students now carry out distance education with student growth rising $3.9 \%$ annually. The high student interest in distance education makes registration on conventional campuses in the United States fall by almost 1 million students in the 2013-2015 period. Clayton Christensen, a professor at Harvard Business School, called the level of comfort and ease of access to personalized knowledge with digital technology the spearhead of distance education. In the next few decades, distance education will probably erode conventional education models that require face to face.

The fifth potential factor is the role of institutions. It is undeniable that the state of a country also influenced by the behavior of existing institutions in the State, both government institutions, private institutions, corporate institutions, and educational institutions. The institution was able to influence the economy of a nation through its respective roles. Including the part of the institution is how they affect the quantity and quality of human resources in a country. The number of sure experts can be influenced by the policies of State institutions and the policies of educational institutions and the exception of actuaries. Therefore, cooperation between institutions is deliberately believed to be able to overcome the shortage 
of actuaries in Indonesia.

This study attempts to examine and analyze how all of these potential factors can be optimized so that they can overcome the problem of sharia actuary scarcity in Indonesia. This study was written in the following order: Chapter 1 describes the reasons or motivations for why this research wrote. Chapter 2 explains the fundamentals of the theory used to define various alternative f solution to deal with the scarcity of actuarial sharia in Indonesia. While Chapter 3 presents the research method used in this study followed by Chapter 4 about the discussion and analysis of solutions offered and ends with Chapter 4, namely conclusions and suggestions.

From the explanation that has been explained above, this study aims to identify the potential and formulating inter-agency cooperation models for certification programs for sharia actuaries as an effort to overcome the scarcity of quality actuary power for Islamic insurance in Indonesia.

\section{Literature Review}

\subsection{The Concept of Distance Education}

In addition to lectures, distance education also used for tutorial systems or tutoring. Distance separated students are put together in study groups guided by one tutor from the central campus. Tutorials are carried out through websites and short and face-to-face messaging applications, depending on the agreement of the students and their tutors. Distance education students' teaching materials consist of digital books (e-books), audio recordings of subject matter, and video material that can download through online stores provided by universities (Kuntarto, 2017).

Wang et al (2013) explains that people who are familiar with digital technology want education to be more flexible. The flexibility that exists in distance education has changed common learning patterns so far, characterized by the absence of physical classrooms, the lack of centralized scheduling from the campus for study time, and the freedom to determine the number of courses taken.

In distance education, the term drops out, and the graduation deadline is not known so students can determine how many courses they want to take without being pursued by the graduation deadline. Wang et al (2013) said that distance education students are free to choose the learning time they think is productive to absorb lecture material so as to allow students to understand the lecture material longer because in distance education the understanding of the material it is more emphasized. Wang et al (2013) also added that following the distance education program, students could manage their own time and encourage them to be more creative. The use of information technology in the distance education system is predicted to be more oriented towards improving human comfort as learners as well as system users.

In this era of modern technology sophistication, we are already familiar with data analysis to see a particular trend. In implementing distance education, data analysis is used to determine the characteristics and learning models of each student. In the conventional education system, the learning model applied to all students is the same, while distance education tries to implement personalized education according to the characteristics of each student. How is data analysis used to conclude? That is, with an online learning track record. When students access teaching materials at online campus stores, open video material pages, and view the same digital book several times, it will show the interest and learning model of a student.

Track records in cyberspace are then processed to provide subject matter that is considered attractive and appropriate for students' interests. The track record can also bring students together with study groups whose members have the same learning interests and models. These advantages offered by distance education encourage students to learn through the distance education system.

Distance education has been adopted in Indonesia since 1984 but has 
notutilized internet technology at that time. The first mandate to hold distance education first given to the Open University (UT). With some active students of more than 350 thousand people throughout Indonesia, Open University (UT) is among the top ten universities in the world with more than 100 thousand students. After several years running, then followed other campuses such as Bina Nusantara University (BINUS), University of Indonesia (UI), GadjahMada University (UGM), Ten November Institute of Technology (ITS), Bandung Institute of Technology (ITB), and Yogyakarta AMIKOM. The seven universities issued distance education learning materials for 30 subjects which were later adopted by 51 universities throughout Indonesia.

Although the distance education system has many advantages, it is undeniable that there are still many obstacles faced in the practice of implementing distance education. The absence of a drop-out system in distance education becomes an advantage and things that students should watch out. If students cannot manage their time correctly, then it will become an obstacle in the completion of their education, coupled with the distance education system which does not require face to face so that the control of the lecturers to students reduced. The next obstacle is online examinations that are still difficult to monitor.

In distance education, the exams are also carried out through an online system. The paradigm of "value is everything" is still firmly embedded in the minds of students. It's a pity if distance education should be able to be used to understand the material longer but not used to study well. On the learning facilities side, there are still limitations to the availability of digital teaching materials. Digital stores and digital teaching materials still constrained by delays in uploading and technical problems with default bugs.

The flexibility of the learning system in distance education is expected to make students fully responsible so that they can attend the lecture and complete it to the full. Mandiri, good at dividing time, and a strong commitment to complete education is the key to success in distance education.

The following are universities that hold distance education in the world and Indonesia:

1. University of Florida

a. Type of distance education: undergraduate, postgraduate, doctoral. Full distance education and multiple models (partially face to face)

b. Study programs: medicine, nursing, distance educationntistry, engineering, business administration, agriculture, pharmacy, education

c. Media: electronic books, practice questions, assignments, teaching videos, default devices

2. School of Oriental and African Studies (SOAS), University of London

a. Type of distance education: full distance education postgraduate

b. Study Program: climate change and regulation, finance and management, diplomacy and science International

c. Media: electronic books, assignments, practice questions, instructional videos and animations, default devices

3. University of Edinburgh

a. Type of distance education: full distance education postgraduate

b. Study Program: medicine, dentistry, veterinary medicine, data science, design, education, health, history, law, philosophy, earth science, and international development

c. Media: electronic books, interactive presentations, online text messages, online question and answer sessions

4. Columbia University

a. Type of distance education: full distance education postgraduate and multiple models

b. Study Program: business, applied mathematics, biomedical engineering, computer science, civil engineering, data science, environmental engineering, electrical engineering

c. Media: electronic books 
5. University of Manchester

a. Type of distance education: undergraduate, full distance education graduate and multiple models

b. Study Program: electrical power system engineering, ethics and health law, management and information systems, public health

c. Media: electronic books, practice questions, assignments, teaching videos, default software

6. Open University (UT)

a. Type of distance education: full distance education degree, multiple and parallel models, full distance education postgraduate

b. Study Program: Mathematics and Natural Sciences, law, economics, elementary education and early childhood education program (PAUD), business administration, government science, English, sociology

c. Media: learning videos, module books, online and face-to-face tutorials

7. University of Indonesia (UI)

a. Type of distance education: undergraduate, distance education and multiple models

b. Study program: computer science, accounting, public health

c. Media: e-learning portal

8. Bina Nusantara University (BINUS)

a. Types of distance education: undergraduate, postgraduate, full distance education and multiple models

b. Study Program: accounting, business management, information systems, informatics engineering

c. Media: learning videos, module books, online and face-to-face tutorials

9. Bandung Institute of Technology (ITB)

a. Type of distance education: undergraduate, full distance education and double model

b. Study Program: Mathematics and Natural Sciences, civil engineering

c. Media: e-learning portal

\subsection{Role of Actuaries in Insurance Companies}

According to Rudas (2008), the essential tasks of actuaries are as follows:

1. Establish premiums for insurance products:

The insurance pricing process is dynamic, involving many parties including market participants for insurance products, management, and marketing division of insurance companies, insurance regulators, and others, actuaries create a core part of this process by balancing insurance company's premium income and payments madistance education by insurance company for benefits, claims, costs, and profit distribution to company owners.

2. Insurance backup arrangements:

Reserves are distance educationfined as expected future payments in the policies that have been borne and currently in effect. Reserves are liabilities of insurance companies that represent claims and amounts of fees, or benefits promised to the insured party when the event mentioned in the insurance policy occurs.

3. Guarantee the solvency of insurance companies, both in the context of short and long-term:

This solvability requirement not only means the standard ability to make scheduled payments, which applies to all companies but also places an additional element of the surplus (or capital) level - defined as the excess of the company's assets on liability - needed to ensure payment to the insured when the probability is high.

The obligation of the insurance company consists almost entirely of reserves. When an insurance company collects insurance premiums, some of them are used to pay fees, such as marketing, administrative, or actuary salaries (this is a 
substantial expense, because actuaries are consistently among the highest paid professionals) and other personnel, while the rest placed in reserve to pay for claims or benefits in the future. In addition to ensuring that the reserve is large enough to cover the actual promised payments, the actuary must provide that the assets and liabilities of the company adequately managed so that the difference between assets and liabilities (surplus) remains at the level required by the insurance regulator, or higher.

The form of management of an insurance company (or other entity involved in risk management) is called asset-liability management and is part of a larger field of management company risk, the right track of a management study of risky activities where every business entity can and must be involved.

\subsection{Insurance Pricing Process by Actuaries}

According to Rudas (2008) explains that Actuaries start the process of insurance pricing by forecasting future claims costs in property, accident, and liability insurance, or benefits in the case of life, disability, or health insurance, and life annuities. For example, in the case of life insurance, this process begins with the study of the future life of the insured provided. If the variable representing the future of life (real number) is protected $x$, the life insurance policy in the specified amount is the present value of the amount discounted from the time of payment (at death or immediately after), the future year T (or the number that approaches $\mathrm{T}$ ), to the present. This fee will likely be adjusted by the insurance company policy, such as marketing, administration and settlement costs.

Furthermore, the actuary estimates the capital costs of an insurance company, and the capital must be paid. This capital cost becomes another expense, added to the price charged to the insured party. If the insurance premium set as the expected value of a random variable that explains future benefit/claim payments and expenses, this pricing method is called the principle of equality.

The most basic principle of price insurance requires the premium to set at a level equal to the expected value (or average) of the future of payment, modeled as a random variable. The diversification process contains many of the combined risks of various insured parties making the average salary more or less equal to the expected theoretical value, as a consequence of the limit theorem of probability theory.

This diversification process may not always be sufficient, and some provisions for actuaries called adverse deviations (deviations from the actual number of total claims or benefits of the expected amount, in a way that is detrimental to insurance companies) must be made by appropriately increasing insurance premiums for cover this risk to the insurance company's capital. Thus, the bonus usually set as the expected value of the claim or benefit (adjusted for the amount of the discounted money) plus the expected value of all costs and taxes plus a provision for risk of adverse deviations - commonly called risk loading - covered by a precise estimate of costs capital is commensurate with the total risk of the insurance company.

\subsection{The role of the Financial Services Authority in the Development of Sharia Insurance in Indonesia}

Financial Services Authority (OJK) as the regulator of the Sharia Non-Bank Financial Industry in Indonesia has a significant role. According to the book Road Map of the Sharia Non-Bank Financial Industry, there are several important points as follows. As explained in the first chapter, Financial Services Authority (OJK) establishes mission III for the Islamic non-bank financial industry (Sharia IKNB), namely increasing human resources, infrastructure and information technology support for the Islamic Financial Industry. In particular, the Financial Services Authority (OJK) entered into strategy II in its third mission, namely by supporting the cooperation of Sharia Non-Bank Financial Industry (Sharia IKNB) related parties to produce more professional human resources in the field of Sharia Non-Bank Financial Industry (Sharia IKNB). 
Financial Services Authority (OJK) also developed a number of action plans to implement the strategy, namely 1) Encouraging the establishment of professional standards institutions in the field of Sharia Non-Bank Financial Industry (Sharia IKNB), 2) Improving cooperation with education and training institutions in the field of Islamic finance, 3) Coordinating with industry associations, professional associations, educational institutions, and communities to capture potential human resource professionals. 4) Encourage education programs for prospective sharia supervisory boards. Whereas in strategy III mission III Financial Services Authority (OJK) has developed a strategy by encouraging the improvement of the application of integrated information systems in the business processes of Sharia Non-Bank Financial Industry (Sharia IKNB) with an action plan 1) strengthening regulations regarding the implementation of integrated information systems of Sharia Non-Bank Financial Industry (Sharia IKNB) and 2) encouraging the application of information systems of Sharia Non-Bank Financial Industry (Sharia IKNB) customers (Sharia Non-Bank Financial Industry Directorate-Financial Services Authority, 2015).

\subsection{The Role of Higher Education in Providing Human Resources for Companies in Student Center Learning (SCL) Curriculum}

Higher Education is another crucial factor in the creation of human resources. Higher education is a place where people build themselves with specific expertise. Academic and technical skills are the output of higher education which is vital for the availability of human resources. With these interests, it is not surprising that the teaching system in universities continues to experience development.

Today, to meet the needs of qualified human resources, the government has established a student center learning (SCL) curriculum. Student center learning (SCL) curriculum emphasizes the efforts of lecturers and all available facilities in the campus to facilitate the achievement of student competencies. Unlike the old curriculum which prioritizes the role of lecturers or instructors in the learning process, the Student Center Learning (SCL) curriculum only plays the role of facilitator. The central character is precisely the students who are trying to achieve a more realistic learning experience by the competencies to be gained.

The method in Student Center Learning $(\mathrm{SCL})$ is more diverse than the methods in the conventional curriculum; the Student Center Learning (SCL) method consists of various approaches such as drama methods, case resolution methods, methods with project assignments, group presentation methods and field study methods.

Universities and colleges have facilities, infrastructure and teaching staff capable of printing human resources. All of these facilities are still equipped with a systematic curriculum system. This curriculum requires that university alumni not only hold academic diplomas and transcripts that contain only grades but also are accompanied by a certificate of attending award that includes information on the ability and competence of alumni. The document consists of the skills and abilities of alumni obtained during college. The letter explains what can be done by a former student. Thus, it has been illustrated how the role of universities in providing reliable human resources.

\subsection{A Gap of College Graduates with Qualifications for Sharia Actuary Requests}

Based on the arguments written in the introductory section, it can be identified that the qualifications of sharia actuaries are having skills in the fields of mathematics, logic, and statistics as well as mastering Islamic law / Sharia, figh, figh proposals, and Islamic teachings well. In general, the classification of tertiary institutions in Indonesia is divided into two, namely public universities and religious colleges.

Dichotomy also raises a different output; public colleges produce graduates who are competent in the field of general sciences while college graduates religion spawned an expert in the field of religion. The Islamic finance industry demands the 
qualifications of human resources which have excellence in two areas of general science (economics, mathematics, positive law, statistics, management, etc.) and at the same time religious knowledge such as Islamic law / Sharia, jurisprudence, ushul figh, Quranic interpretation, Arabic and so on. Public universities excel at printing.

\subsection{The Role of the Indonesian Sharia Insurance Association (AASI) for the Provision of Sharia Insurance Human Resources}

In Indonesia, the Indonesian Syariah Insurance Association (AASI) concept is the embodiment of the Islamic Insurance Society (IIS). Mujiharto (2009) states that role Islamic Insurance Society (IIS) with certification program of expertise in human resources development Takaful namely:

a. Improve and develop the quality of professionalism of Islamic insurance business players

b. Assist the government in fulfilling experts in the field of sharia guarantee

c. Increasing understanding and target of community sharia insurance

d. Participate in enhancing the role of the insurance industry in the development

e. Spur the growth of Islamic insurance in Indonesia

f. As an extension of the National Sharia Council (DSN) in translating fatwas fatwa in the insurance sector

Mujiharto (2009) also concluded that the Islamic Insurance Society (IIS) had made efforts in the development of Sharia Insurance Human Resources namely by improving the performance of teaching staff, education syllabi, exam materials and education curriculum by increasing standards of competence, improving qualifications and cooperating with facilities other education. External efforts are also carried out bylslamic Insurance Society (IIS), which is to carry out sharia insurance expertise certification activities every year and carry out in-house training in Islamic insurance companies.

\subsection{The Role of The Indonesian Actuary Association (PAI) for The Provision of Actuary Power in Indonesia}

The Indonesian Association of Actuaries, abbreviated as Indonesian Actuary Association (PAl), is called The Society of Actuaries of Indonesia in English, is a national organization of actuary professions in Indonesia dedicated to providing services to the general public and its members.

Indonesian Actuary Association (PAl) was founded on October 19, 1964, with 25 members at that time. Over the years, government regulations regarding the insurance industry and pension funds that require the expertise of an the Fellowship of the Society of Actuaries of Indonesia (FSAl) have contributed to the growth of the actuary profession in Indonesia and resulted in government recognition of the Fellowship of the Society of Actuaries of Indonesia (FSAI).

Indonesian Actuary Association (PAI) issues guidelines on Actuarial Standards and Actuarial Code of Ethics which contains instructions for professional practice and standards of the code of conduct that must be carried out. This guideline helps members regarding professional standards that are considered reasonable in the various opportunities they face. Indonesian Actuary Association (PAl) also issued instructions regarding the member disciplinary process to ensure compliance with professional practices and the rules of the code of ethics of its members. Indonesian Actuary Association (PAl) has been a member of the International Actuarial Association (IAA) since 2007. As a member of international organizations, Indonesian Actuary Association (PAI) represents Indonesian actuaries in the international arena and collaborates with other actuarial organizations from mutual interests.

\section{Research Methods}

This type of research used by the author in writing this research uses descriptive qualitative research approach. According to Bogdan and Taylor in Moleong (2010: 
4), qualitative research is "a research procedure that produces descriptive data in the form of written or oral words from people and observable behavior". Descriptive method is considered to be update with current events and present conditions. Furthermore, Nazir (2011: 52) argues that the descriptive method is a method that examines the status of human groups, a subject, a condition, a system of thought or even events at the present time. The purpose of this descriptive study is to make a systematic description, captures the relationship between the phenomena investigated. Thus, the use of qualitative descriptive research approaches and types is expected to provide a valid interpretation of the phenomena that occur in the field.

Research method of this study is literature study. Eckstein (2018: 4) states that literature study is not only a summary or direct quotation sourced from books or articles or journals, but the method focuses on paraphrasing from various sources to strengthen one opinion with another opinion, which is then developed and concluded with good narration without leaving bibliographic references.

\section{Result and Discussion}

\subsection{The Potential of Distance Certification of Sharia Actuaries in Indonesia}

The implementation of distance education has been carried out in Indonesia for a long time. The performance of distance education in Indonesia has increased from year to year. This contributed to the creation of a certification program for sharia actuaries in Indonesia. The certification program for sharia actuary is a program in which the program participants are expected to have the title of sharia actuary in all its competencies.

This program contains the delivery of material that is online and is supported by online practice exercises. In the final stage of the program, participants face professional competency exams and certification online. There are two options for the arrival of the assessor, namely the first option for the certification program participants to move actuaries to the providers of certification programs, ranging from sharia actuaries and the second option, assessors visiting cities where certification program participants travel to Islamic sharia actuaries. Online examinations are a necessity because to maintain the quality of the competencies of program participants and to avoid cheating.

\subsection{The Potential Role of the Financiall Services Authority (OJK) in the Shariah Actuary Certification Program in Indonesia}

The role of Financial Services Authority (OJK) is as a regulator in the field of developing Islamic insurance human resources. Financial Services Authority (OJK) can issue regulations that regulate distance education for prospective sharia actuary candidates in Indonesia. The law includes the attestation of distance education programs actuarial studies, statistics and actuarial organized by the Indonesian universities and colleges abroad can be recognized to be a requirement to follow certification actuary sharia. Distance education in actuarial science, statistics, and jolly open for a prospective actuary with the terms Syariah requirements stipulated by law colleges such as the lower limit and the upper limit of age and is a high school or equivalent alumni.

Financial Services Authority (OJK) can also make rules regarding the acceleration program of actuarial certification for students of actuarial study programs, mathematics, and statistics by issuing regulations that recognize that the placement of several subjects during their time in college is equated with material for certification programs. With qualification standards differ between the actuary conventional insurance and Takaful, the need for standard qualification actuary Shariah also varies, one feature in particular is the actuary must have a powerful ability in the field of Islamic Law/Sharia, Figh Ushul Figh and Jurisprudence Muamalah main for those who major in Sharia/Islamic Law.

Faced with this, graduates of Islamic economic study programs or Islamic economics study programs or graduates from Islamic higher education institutions 
have advantages in this field. Graduates of Islamic economics study programs or state islamic university (UIN) alumni have received material concerning Islamic law. Thus, as with alumni statistics and mathematics, to accelerate the availability of sharia actuary human resources, Financial Services Authority (OJK) needs to issue a regulation that recognizes the existence of equality of opinion has taken certification material for sharia faculty alumni. Especially for alumni majoring in mathematics and studying at the campus of Islam. Some Islamic universities integrate religion and general science.

The role of Financial Services Authority (OJK) then is to establish a sharia actuary profession certification institution. The reason for the importance of forming these institutions is the difference between conventional insurance actuaries and Islamic insurance actuaries.

\subsection{The Potential Role of Higher Education Institutions in the Shariah Actuary Certification Program in Indonesia}

Universities as the place for prospective actuaries are forged and educated to achieve competent competencies. The existence of Student Centered Learning (SCL) which is a demand for the law is a great potential so that material about actuarial and sharia can be absorbed better. The role of universities is vast in preparing a student before becoming an actuary. The basic sciences regarding mathematics and logic are taught systematically in college so that it becomes an essential provision in becoming a sharia actuary. Likewise with the science of sharia has also been shown in the Islamic college. Science is a necessary provision for a sharia actuary. The process of completing courses on actuarial material and sharia material in higher education is a shortcut for prospective certification program participants from sharia actuaries. Subjects that are involved and successfully graduated and per the certification competence can be equalized into semester credit or material credit for participants of the certification program for sharia actuaries.

Higher education also has the potential to become an actuary profession campaigner. The lecturers have the opportunity to explain the actuary profession to students by explaining what, how and how much the actuary earns. Higher education institutions have the potential also to be part of the long-distance certification program, namely universities that run distance education programs with both actuarial and sharia material. Universities can facilitate all communities from across the archipelago to get material on actuarial and Islamic legal document.

The study program that has been accredited by National Accreditation Institution of Higher Education (BAN-PT) value A is considered to have the potential to carry out distance education and participate in the Syariah actuarial certification material matching program. Table 1 in the appendix shows a list of Actuarial, Statistics and Mathematics Study Programs with A Accreditation that has the potential to cooperate with Financial Services Authority (OJK) and the other parties about the certification program for the distance between sharia actuaries. Potential to collaborate with Financial Services Authority (OJK) regarding the sharia actuary program certification program while Table 3 lists the Sharia Economic Law study programs that received the title A from National Accreditation Institution of Higher Education (BAN-PT).

\subsection{The Potential Role of the Indonesian Islamic Insurance Association (AASI) in the Shariah Actuary Certification Program in Indonesia \\ Indonesian Syariah Insurance Association (AASI) has the main task, among others (AASI, 2018): \\ a. Exchange information between members. \\ b. Monitor mass media coverage about Islamic insurance and member activities. \\ c. Conduct approaches and good relations with Government Agencies and Non- Government Institutions/Agencies that are related to member business}


activities. Creating business opportunities and directing members to foster national and international cooperation.

d. Recommend tariffs, standardize policies and clauses according to member needs.

e. Accreditation of professional certification bodies in the field of Islamic insurance.

Indonesian Syariah Insurance Association (AASI) member is an insurance company that organizes all or part of its business based on sharia principles. So the participation of Indonesian Syariah Insurance Association (AASI) in the Distance Sharia Actuary Certification Program will provide trainees knowledge about Sharia Insurance operations and governance and include the functions and roles of Sharia Actuaries.

The role of Sharia Insurance Association of Indonesia (AASI) as a speaker ODL (Distance Learning) certification program Actuaries Sharia

1. Referring to the main tasks of Indonesian Syariah Insurance Association (AASI), the material that can be delivered by the Indonesian Syariah Insurance Association (AASI) Speaking Team to training participants is Sharia Insurance Operations, Sharia Insurance Management, Sharia Insurance Risk Management and the role and function of Sharia Actuaries in Sharia insurance

2. There are differences in the method of delivering the material initially to the Indonesian Sharia Insurance Association (AASI) in the form of lectures in class and followed by the trainees directly. While the method of delivery of material to the trainee program long-distance certification Actuaries Sharia is in ODL namely presenters Indonesian Syariah Insurance Association (AASI) utilizing technology such equipment in the form of a file upload soft copy and video on Sharia Actuaries certification page. And the training participants' understanding mechanism can also be done through the page. Training participants can access the material flexible and use it online

3. Distance education training methods will facilitate training teams where there is no need to attend and face to face with training. And the Indonesian Sharia Insurance Association (AASI) presentation team is more able to focus more on preparing the material by the specified period following the target time of the training. The speaker business will be more massive at the beginning of the lecture because they have to prepare material on different media such as videos that are easily understood by trainees and so on the soft copy of the article. But after running a training period, it will be beneficial for the speaker in the next training because only preparing the material using a database previous period material. And the content can at least be updated when there are recent policy changes on Sharia Actuaries and Sharia Insurance.

4. With the distance education method, the Indonesian Sharia Insurance Association (AASI) still provides an evaluation or assessment of the understanding of the participants' training material. The creativity of the Indonesian Syariah Insurance Association (AASI) presentation team is needed in making evaluation questions related to understanding the training material through a series of competency tests for the Sharia Actuary profession. Due to the results of the evaluation or assessment is paramount in describing and evaluating the quality of the material and also the quality of trainee program long-distance Actuaries Sharia.

The role of Sharia Insurance Association of Indonesia (AASI) as assessors program long-distance Actuaries Sharia

1. Assessors program Long distance Certification Actuaries Sharia has the task of measuring the ability of the trainee program Longdistance Certification Actuaries Sharia through a series of competency tests the strength of the profession in the trainees as Sharia Actuaries.

2. Assessors program Long distance Certification Actuaries Sharia has the 
authority to certify the results of the competency exam on the ability of a trainee as the Islamic Actuary together with the Certification Team Actuaries Sharia. The Sharia Actuary Certification Team consists of the Indonesian Actuary Association (PAI), the Indonesian Sharia Insurance Association (AASI), National Sharia Council (DSN)-Indonesian Ulema Council (MUI), and the Financial Services Authority (OJK).

3. The entire team of presenters Sharia Insurance Association of Indonesia (AASI) is assessor program Long distance Certification Actuaries Sharia.

\subsection{The Potential Role of the Indonesian Actuary Association (PAl) in the Shariah Actuary Certification Program in Indonesia}

The Indonesian Association of Actuaries abbreviated as Indonesian Actuary Association (PAI) or in English called The Society of Actuaries of Indonesia is a national organization of actuary professions in Indonesia dedicated to providing services to the general public and its members. Indonesian Actuary Association (PAl) founded on October 19, 1964, with 25 members at that time. Indonesian Actuary Association (PAl) issues guidelines on Actuarial Standards and Actuary Code of Ethics which contains instructions for professional practice and standards of the code of conduct that must be carried out. This guideline helps members regarding professional standards that are considered reasonable in the various opportunities they face. Indonesian Actuary Association (PAI) also issued instructions regarding the member disciplinary process to ensure compliance with professional practices and the rules of the code of ethics of its members (PAl, 2018).

In Indonesia, Indonesian Actuary Association (PAl) is an institution that has experience in providing training and testing and certifying the Actuary profession. The role of Indonesian Actuary Association (PAI) in delivering training in actuarial matters is therefore necessary because there is no institution specifically to test and verify the Sharia Actuary profession. The hope of this concept combines several institutions to be able to produce professional Sharia Actuaries.

Role of Society of Actuaries of Indonesia (PAl) as a speaker ODL (Distance Learning) program Longdistance Certification Actuaries Sharia

1. Referring to the guidelines of the Professional Examination and Indonesian Actuary Association Certification (PAI) related to education and training that have held which teaches material about being tested at ASAl levels of Financial Mathematics, Probability, and Statistics, Economics, Accounting, Statistics Methods, Actuarial Mathematics, Modeling and Risk Theory. While the material tested at the Fellowship of the Society of Actuaries of Indonesia (FSAI) level is about all ASAl Levels, Investment and Management, Actuarial Management, Actuarial Aspects in Life Insurance, Actuarial Aspects in Pension Funds, Actuarial Aspects in General Insurance, Actuarial Aspects in Health Insurance. The entire Indonesian Actuary Association (PAI) material tested at ASAl and the Fellowship of the Society of Actuaries of Indonesia (FSAl) levels is a whole series of articles that are also needed by Sharia Actuaries and delivered by the Indonesian Actuary Association (PAl) speaker team.

2. There are differences in the method of delivering the material initially at the Indonesian Actuarial Association (PAl) in the form of lectures in class and followed by trainees directly. While the process of delivery of content to the trainee Longdistance Certification Actuaries Sharia is in ODL namely Indonesian Actuary Association (PAI) presenters utilizing technology such material in the form of a file upload soft copy and video on Sharia Actuaries certification page. And the training participants' understanding mechanism can also be done through the page. Training participants can access the material flexible and use it online.

3. Distance education training methods will facilitate training teams where there is no need to attend and face to face with training. And the group of Indonesian Actuaries Association (PAI) is more able to focus more on preparing the material following the specified time under the target time of the training. 
The speaker business will be more cumbersome at the beginning of the lecture because they have to prepare material on different media such as videos that are easily understood by trainees and so on the soft copy of the article. But after running a training period, it will be constructive for the speaker in the next training because only preparing the material using a database previous period material. And the content can at least be updated when there are recent policy changes on Sharia Actuaries and Sharia Insurance.

4. With the method of distance education, the Indonesian Actuary Association (PAI) still provides an evaluation or assessment of the understanding of the participants' material. Creativity is needed by the Indonesian Actuary Association (PAl) speaker team in making evaluation questions related to understanding the training material through a series of competency tests for the Sharia Actuary profession. Due to the results of the evaluation or assessment is significant in describing and evaluating the quality of the material and also the quality of trainee program Long distance Certification Actuaries Sharia.

Role of Society of Actuaries of Indonesia (PAI) as assessors program Long distance certification Actuaries Sharia

1. Assessors Longdistance Certification Actuaries Sharia has the task of measuring the ability of the trainee program Long-distance Certification Actuaries Sharia through a series of competency tests the strength of the profession in the trainees as Sharia Actuaries.

2. Assessors program Long-distances Certification Actuaries Sharia has the authority to certify the results of the competency exam on the ability of a trainee as the Islamic Actuary together with the Certification Team Actuaries Sharia. The Sharia Actuary Certification Team consists of the Indonesian Actuary Association (PAl), the Indonesian Sharia Insurance Association (AASI), National Sharia Council (DSN)-Indonesian Ulema Council (MUI), and the Financial Services Authority (OJK).

3. The entire team of presenters Society of Actuaries of Indonesia (PAI) is the assessor program Long-distance Certification Actuaries Sharia.

\subsection{Potential Role of Indonesian Ulama Council(MUI) in the Sharia Actuary Distance Certification Program in Indonesia}

One of the roles of the Indonesian Ulema Council (MUI) according to the history of MUI (2016), which is to provide guidance and guidance to Indonesian Muslims in realizing the religious and social life that is blessed by Allah Subhanahu Wa Ta'ala. The support given by the Indonesian Ulema Council (MUI) in the development of Islamic Financial Institutions was the establishment of the National Sharia CouncilIndonesian Ulema Council (DSN-MUI) on February 10, 1999. DSN-MUI was formed to carry out the Indonesian Ulema Council's (MUI) task in establishing fatwas and supervising its application to develop business fields Islamic finance, business and economics in Indonesia.

Furthermore, the National Sharia Council-Indonesian Ulema Council (DSN MUI) established a particular training institute, namely the National Sharia CouncilIndonesian Ulema Council (DSN MUI) Institute based on the Decree of the Indonesian Ulema Council Leadership Council Number: Kep-121 1/MUI/XI/2017. DSN MUI Institute as part of the Field of the National Sharia Council-Indonesian Ulema Council (DSN MUI) Executive Board (BPH) which functions as a center for education, training, socialization and fatwa literacy as well as Up-grading for candidates for Sharia Supervisory Board (DPS) and/Sharia Supervisory Board (DPS) in Islamic Financial Institutions (DSN-MUI, 2017).

MUI's role through the National Sharia Council-Indonesian Ulema Council (DSN MUI) Institute in support of the program Longdistance- Certification Actuaries Sharia is as follows:

The purpose of the Institute as a speaker National Sharia Council-Indonesian Ulema Council (DSN MUI) ODL (Distance Learning) Long-distance Certification 
Actuaries Sharia:

1. Referring to the profile of National Sharia Council-Indonesian Ulema Council (DSN MUI) Institute related to education and training that has been held which teaches material on National Sharia Council-Indonesian Ulema Council (DSN MUI) fatwa and MuamalatMaliyah and National Sharia Council-Indonesian Ulema Council (DSN MUI) fatwa socialization and literacy are materials that are also needed by Sharia Actuaries. The material presented by the speakers from the National Sharia Council-Indonesian Ulema Council (DSN MUI) Institute is about the National Sharia Council-Indonesian Ulema Council (DSN MUI) and Muamalat Maliyah fatwas specifically concerning Sharia Actuary and Sharia Insurance, the primary material taught to trainees.

2. There are differences in the method of delivering the material initially at the National Sharia Council-Indonesian Ulema Council (DSN MUI) Institute in the form of lectures in class and attended by the trainees directly. While the process of delivery of content to the trainee program Long-distance Certification Actuaries Sharia is in ODL, namely National Sharia Council-Indonesian Ulema Council (DSN MUI) Institute Brazing technology utilizes materials such as uploading a file in the form of soft copy and video on Sharia Actuaries certification page. And the training participants' understanding mechanism can also be done through the page. Training participants can access the material flexible and use it online.

3. Distance education training methods will facilitate training teams where there is no need to attend and face to face with training. And the National Sharia Council-Indonesian Ulema Council (DSN MUI) Institute's presentation team is more able to focus more on preparing the material according to the specified time following the target time of the training. The speaker business will be more substantial at the beginning of the lecture because they have to prepare material on different media such as videos that are easily understood by trainees and so on the soft copy of the article. But after running a training period, it will be constructive for the speaker in the next training because only preparing the material using a database previous period material. And the content can at least be updated when there is the latest National Sharia Council-Indonesian Ulema Council (DSN MUI) fatwa on Sharia Actuaries and Sharia Insurance.

4. With the distance education method, the National Sharia Council-Indonesian Ulema Council (DSN MUI) Institute speaker still provides an evaluation or assessment of the understanding of the participants' material. The creativity of the National Sharia Council-Indonesian Ulema Council (DSN MUI) Institute speaker team is needed in making evaluation questions related to understanding training materials through a series of competency tests for the Sharia Actuary profession. Due to the results of the evaluation or assessment is critical in describing and evaluating the quality of the material and also the variety of trainee program Long-distance Certification Actuaries Sharia.

The role of the Institute as an assessor National Sharia Council-Indonesian Ulema Council (DSN MUI) program Long-distance Certification Actuaries Sharia:

1. Assessors Long-distance Certification Actuaries Sharia has the task of measuring the ability of the trainee program Long-distance Certification Actuaries Sharia through a series of competency tests the strength of the profession in the trainees as Sharia Actuaries.

2. Assessors program Long-distance certification Actuaries Sharia has the authority to certify the results of the competency exam on the ability of a trainee as the Islamic Actuary together with the Certification Team Actuaries Sharia. The Sharia Actuary Certification Team consists of the Indonesian Actuary Association (PAl), the Indonesian Sharia Insurance Association (AASI), National Sharia Council-Indonesian Ulema Council (DSN MUI) Institute and the Financial Services Authority. 
3. The entire team of presenters National Sharia Council (DSN) Insitute is the assessor Long-distance Certfication Actuaries Sharia.

\section{Conclusion and Recommendation}

Whereas the results of the study indicate that there is potential for cooperation in organizing a certification program for sharia actuaries. Some parties referred to include Financial Services Authority (OJK) as coordinators, public universities and Islamic universities as providers of sharia actuary candidates, the Indonesian Syariah Insurance Association (AASI) as material providers and certification examiners, Indonesian Actuary Association (PAl) as material providers and Indonesian Ulema Council (MUI) certification and National Sharia Council (DSN) examiners as material providers and certification examiner.

\section{References}

[1] Ali, A. H. 2009. Asuransi dalam perspektif Islam. Jakarta: UIN Syarif Hidayatullah Press.

[2] Allen, I. Elaine, and Jeff Seaman. 2017. "Distance education enrollment report 2017." Digital learning compass.

[3] Center of Educational Development-Gadjah Mada University, Pusat Pengembangan Pendidikan (PPP) UGM. 2010. Student-Centered Learning (SCL) and Student Teacher Aesthetic Role-Sharing (STAR). Yogyakarta: UGM Press.

[4] Djaelani, F. 2011 . "Pertumbuhan industri asuransi jiwa di Indonesia: Suatu kajian dari sisi penawaran." Jurnal Kawistara, 1 (3).

[5] Dwiharjo, U. 2015. "Upaya Perguruan Tinggi (PT) dalam Meningkatkan Peran Statistik dan Aktuaria untuk Merevitalisasi Industri Asuransi dan Dana pensiun Dalam Era Pasar Bebas Asean 2015 (MEA)." Jurnal Academia Vol 2 No.3.

[6] Eckstein, Jessica J. 2018. The SAGE Encyclopedia of Communication Research Methods, Chapter: Writing a Literature Review. Thousand Oaks: SAGE Publications, Inc.

[7] Kuntarto, Eko. 2017. "Keefektifan Model Pembelajaran Daring dalam Perkuliahan Bahasa Indonesia di Perguruan Tinggi." Indonesian Language Education and Literature 3, 1: 99-110.

[8] Kurnia, D. 2017. "Analisis Deskriptif Kinerja Aktuaris Dalam Penetapan Premi Asuransi Syariah."Journal of the Islamic State Faculty of Economics and Business, Sultan Maulana Hasanuddin Banten.

[9] Moeloeng, L. J. 2010. Metode Penelitian Kualitatif. Bandung: Remaja Rosdakarya.

[10] Mujiharto, A. 2009. "Peranan Islamic Insurance Society Dengan Program Sertifikasi Keahlian Dalam Pengembangan SDM Asuransi Syariah." UIN Syarif Hidayatullah.

[11] Nazir, M. 2011. Metode Penelitian. Jakarta: Ghalia Akasara.

[12] Rudas, T. (2008). Handbook of probability: Theory and applications. Sage Publications.

[13] The Indonesian Syariah Insurance Association, AASI. 2018. "Profile of the Indonesian Sharia Insurance Association." https://www.aasi.or.id/page/visidan-misi. In the access Tuesday, July 31, 2018. Street vendors. 18.14.

[14] The Indonesian Ulema Council, MUI. 2016. "History of the Indonesian Ulema Council." http://mui.or.id/id/category/profile-asarana/sejarah-mui/. In the access Tuesday, July 31, 2018. Street vendors. 15.00

[15] The Indonesian Actuary Association, PAl. 2018. "About Us PAI (The Indonesian Actuary Association)." https://aktuaris.or.id/page/content/172/ about. In the access Tuesday, July 31, 2018. Street vendors. 18.00.

[16] The National Sharia Council-Indonesian Ulema Council, DSN-MUI. 2017. "Profile of DSN-MUI Institute." http://dsnmuiinstitute.com/profil/. In the access Tuesday, July 31, 2018. Street vendors. 15.20.

[17] The Sharia Non-Bank Financial Industry Directorate-Financial Services 
Authority, Direktorat IKNB Syariah-OJK. The. 2015. "Roadmap Industri Keuangan Non-Bank (IKNB) Syariah 2015-2019." Government Document.

[18] Wang, Chih-Hsuan, David M. Shannon, and Margaret E. Ross. 2013 "Students' characteristics, self-regulated learning, technology self-efficacy, and course outcomes in online learning." Distance Education 34, 3: 302-323.

[19] http://www.beritasatu.com/galeri-foto/608-peserta-tes-cpns-membludak.html accessed on July 31, 2018

[20] https://bisnis.tempo.co/read/1043368/industri-asuransi-nasional-tumbuh-tapisangat-kekurangi-aktuaris accessed on July 31, 2018.

[21] https://www.ristekdikti.go.id/its-buka-aktuaria-untuk-pukup-klukan-aktuaris-diindonesia/ accessed on 31 July 2018. 